\title{
FAKTOR-FAKTOR YANG BERHUBUNGAN DENGAN KEJADIAN KETUBAN PECAH DINI PADA IBU BERSALIN DI BPM SRI PUSPA KENCANA, AMD.KEB. DI KABUPATEN BOGOR
}

\author{
Dhinda Fitri Puspita, Kiki Novianty, Annisa Fitri Rahmadini \\ Akbid Prima Husada Bogor \\ dhindafitri22@gmail.com
}

\begin{abstract}
Abstrak
Ketuban Pecah Dini (KPD) yaitu pecahnya ketuban yang terjadi sebelum waktunya yaitu kurang dari 37 minggu dari usia kehamilan. Penelitian ini bertujuan untuk mengetahui faktor hubungan KPD dengan paritas, jumlah cairan ketuban, kelainan letak, dan usia penelitian ini menggunakan purposive sampling dengan menggunakan rekam medis data yang di ambil sebanyak 157 wanita melahirkan dengan 32 KPD dan 125 tidak KPD dari kedua kelompok tersebut dicari hubungan dengan hasil penelitian didapatkan hasil yang mengalami KPD dan tidak KPD dengan hasil penelitian tidak adanya hubungan antara paritas dengan KPD, tidak ada hubungan antara jumlah cairan ketuban dengan KPD, adanya hubungan antara kelainan letak dengan KPD, tidak ada hubungan antara usia dengan kejadian KPD. Diharapkan dari hasil penelitian ini dapat meningkatkan ilmu pengetahuan pada ibu hamil khususnya tanda bahaya pada kehamilan menjelang persalinan untuk mendeteksi terjadinya Ketuban Pecah Dini.
\end{abstract}

Kata Kunci: KPD, Paritas, Jumlah cairan Ketuban, Kelainan Letak, Usia

\section{Pendahuluan}

\section{Menurut data WHO (World Health}

Organization) Tahun 2017 sekitar 810 wanita meninggal, pada akhir tahun mencapai 295.000, 94\% diantaranya terdapat negara berkembang Sedangkan data AKI indonesia secara umum pada tahun 2019 terjadi penurunan dari 395 menjadi 305/100.000 kelahiran hidup (Kementerian Kesehatan RI, 2019)

Bedasarkan data DinKes Provinsi Jawa Barat mencatat di tahun 2020 besar kematian ibu yang melahirkan terlaporkan sebanyak 479 jiwa (579.037 kelahiran hidup) sedangkan data AKI di bogor pada tahun 2020 kematian ibu berjumlah 44 
JOURNAL OF MIDWIFERY CARE :

VOL. 02 No. 01, DESEMBER 2021

DOI : $10.34305 / J M C . V 2 I 01.364$
Ciptaan disebarluaskan di bawah

Lisensi Creative Commons Atribusi-

NonKomersial-BerbagiSerupa 4.0 kasus yang terlaporkan dari angka kelahiran hidup sebanyak 117.040 dari jumlah lahir hidup (Profil Kesehatan Dinkes Kota Bogor, 2020).

Penyebab kematian ibu masih didominasiidengan kejadian oleh hipertensi $28 \%$, perdarahan $29 \%$ dan KPD $10,7 \%$ dari seluruh persalinan. masalah KPD Praterm di dunia dan Indonesia memerlukan perhatian yang khusus.

Menurut Kemenpa RI pada 2018 jumlah angka kematian bayi (AKB) sebanyak 15/1000 kelahiran hidup sedangkan jumlah AKB di jawa barat yaitu sebanyak 1.866 bayi dari 868.655 angka kelahiran hidup. Dan untuk wilayah Kabupaten Bogor jumlah kematian bayi yang terlapor sebanyak 44 orang (117.040 angka kelahiran hidup), infeksi pada masa intranatal Sebagian besar disebabkan oleh ketuban pecah dini sebanyak 65\% (Profil Kesehatan Dinkes Kota Bogor, 2017).

\section{Menurut World Health} Organization (WHO) angka kejadian KPD di dunia pada tahun 2017 sebanyak 5060\% (Wulandari et al., 2019), Bedasarkan data di Indonesia sebanyak 65\%, terjadinya ketuban pecah dini terjadi pada tahun 2020 angka kejadian ketuban pecah dini di jawa barat sebanyak 230 kasus dari 4834 (4,75\%) kebanyakan kasus kematian ibu itu disebabkan pada saat persalinan juga masa nifas (Wulandari et al., 2019). Sedangkan data dinas kesehatan jawa barat angka kejadian ketuban pecah dini pada tahun 2017 di laporkan yakni sebanyak 230 kasus dari angka persalinan 4834 (4,75\%) (Hartina, 2017). Sedangkan menurut dinkes kabupaten bogor sebanyak 12 kasus kematian ibu atau 56,83/100 ribu kelahiran hidup yang mengalami KPD (3\%) (Kementerian Kesehatan RI, 2017)

Ketuban Pecah Dini (KPD) yakni pecahnya selaput amnion (ketuban) sebelum munculnya tanda-tanda persalinan yang diobservasi 1 jam sebelum terjadinya inpartu. KPD terjadi karena selaput mengalami robekan, muncul setelah usia kehamilan mencapai 28 minggu dalam 8 sampai dengan $10 \%$ wanita hamil lebih dari 40 minggu beresiko KPD. Jadi ketuban pecah dini yakni pecahnya ketuban sebelum waktunya inpartu (Manuaba, 2009).

Penyebab KPD belum dilihat secara pasti apa yang menyebabkan seseorang ketuban pecah dini, namun yang menjadi faktor antara lain infeksi yang terjadi langsung pada selaput ketuban yang abnormal pada faktor yang meliputi paritas, jumlah air ketuban, kelainan letak, 
JOURNAL OF MIDWIFERY CARE :

VOL. 02 No. 01, DESEMBER 2021

DOI : $10.34305 / J M C . V 2 I 01.364$

cephal polvic disproportion, dan pendular abdomen (Sagita, 2016)

Dengan cara mendiagnosa kejadian ketuban pecah dini pada ibu bersalin menggunakan Tes $\mathrm{PH}$ untuk mengetahui keasaman dari vagina, apabila keasaaman seimbang bisa di pastikan cairan yang keluar adalah cairan ketuban. Dan melakukan USG untuk mengetahui letak posisi janin (Sunarti, 2017).

Bedasarkan studi pendahuluan, didapatkan bahwa data jumlah kejadian ketuban pecah dini tahun 2018 sebanyak 33 kejadian (17\%) dari 197 angka persalinan normal, sedangkan tahun 2019 sebesar 42 kejadian (19\%) dari 221 angka persalinan normal.
Ciptaan disebarluaskan di bawah

Lisensi Creative Commons Atribusi-

NonKomersial-BerbagiSerupa 4.0 Internasional.

\section{Metode}

Jenis penelitian ini menggunakan survey analitik dengan pendekatan purposive sampling . Populasi dalam penelitian ini adalah kejadian ketuban pecah dini pada tahun 2020 dengan jumlah persalinan 259 dan terjadinya kejadian ketuban pecah dini sebanyak 53 kejadian di BPM Sri Puspa Kencana, Amd. Keb dengan jumlah sampel 157 dengan metode purposive sampling.

Pengambilan data menggunakan data sekunder yang didapatkan dari rekam medis. Analisa univariat dilakukan pada setiap variabel faktor - faktor yang berhubungan dengan kejadian ketuban pecah dini pada ibu bersalin (B. Rahayu \& Sari, 2017).

Analisa bivariat dilakukan dengan uji chi square.

\section{Hasil}

Tabel 1. Distribusi Frekuensi terhadap Ketuban Pecah Dini

\begin{tabular}{ccc}
\hline Ketuban Pecah Dini & $\mathbf{n}$ & $\mathbf{\%}$ \\
\hline KPD & 32 & 20.4 \\
Tidak KPD & 125 & 79.6 \\
\hline Total & $\mathbf{1 5 7}$ & $\mathbf{1 0 0}$ \\
\hline
\end{tabular}

Tabel 1 Distribusi Frekuensi

Berdasarkan Ketuban Pecah Dini di BPM

Sri Puspa Kencana,Amd.Keb Tahun 2020 menunjukan kejadian Ketuban Pecah Dini di wilayah kerja BPM Sri Puspa Kencana, Amd.Keb. Dari 157 sampel yang tersedia 
Tidak KPD 125 (79.6\%) Dan KPD 32

dengan tidak KPD.

$(20,4 \%)$ Sebagian besar adalah persalinan

Tabel 2. Distribusi Frekuensi terhadap Paritas

\begin{tabular}{ccc}
\hline Paritas & $\mathbf{n}$ & $\mathbf{\%}$ \\
\hline Primipara & 98 & 62.4 \\
Multipara & 59 & 37.6 \\
\hline Total & $\mathbf{1 5 7}$ & $\mathbf{1 0 0}$ \\
\hline
\end{tabular}

Tabel 2 mennunjukan Paritas di bahwa primipara sebanyak 98 (62.4\%) dan wilayah kerja BPM Sri Puspa Kencana, pada multipara 59 (37.6\%).

Amd.Keb dari 157 sampel menunjukan

\section{Tabel 3. Distribusi Frekuensi terhadap Jumlah Cairan Ketuban}

\begin{tabular}{ccc}
\hline Jumlah Cairan Ketuban & $\mathbf{n}$ & $\mathbf{\%}$ \\
\hline Oligohidromion & 7 & 4.5 \\
Cukup & 150 & 95.5 \\
\hline Total & $\mathbf{1 5 7}$ & $\mathbf{1 0 0}$ \\
\hline
\end{tabular}

Tabel 3 mennunjukan jumlah cairan ketuban di wilayah kerja BPM Sri Puspa Kencana, Amd.Keb dari 157 sampel menunjukan bahwa cairan ketuban yang cukup sebanyak $150 \quad(95.9 \%)$ dan oligohidromion sebanyak 7 (4.5\%).

Tabel 4. Distribusi Frekuensi terhadap Kelainan Letak Janin

\begin{tabular}{ccc}
\hline Kelainan Letak Janin & $\mathbf{n}$ & $\mathbf{\%}$ \\
\hline Normal & 156 & 99.4 \\
Sungsang & 1 & 0.6 \\
\hline Total & $\mathbf{1 5 7}$ & $\mathbf{1 0 0}$ \\
\hline
\end{tabular}

Tabel 4 menunjukan kelainan letak janin di wilayah kerja BPM Sri Puspa 
Kencana, Amd.Keb dari 157 sampel normal sebanyak $156 \quad(99,4 \%)$ dan menunjukan bahwa kelainan letak janin kelainan letak sungsang hanya $1(0,6 \%)$.

\section{Tabel 5. Distribusi Frekuensi terhadap Usia}

\begin{tabular}{ccc}
\hline Usia & $\mathbf{n}$ & $\mathbf{\%}$ \\
\hline Produktif & 88 & 56.1 \\
Non Produktif & 69 & 43.9 \\
\hline Total & $\mathbf{1 5 7}$ & $\mathbf{1 0 0}$ \\
\hline
\end{tabular}

Tabel 5 mennunjukan usia di bahwa usia produktif sebanyak $88(56,1 \%)$ wilayah kerja BPM Sri Puspa Kencana, dan usia non produktif $69(43,9 \%)$. Amd.Keb dari 157 sampel menunjukan

Tabel 6. Hubungan Paritas Terhadap Kejadian Ketuban Pecah Dini pada Ibu Bersalin di BPM Sri Puspa Kencana, Amd.Keb Kabupaten Bogor Tahun 2020

\begin{tabular}{|c|c|c|c|c|c|c|c|}
\hline \multirow{3}{*}{ Paritas } & \multicolumn{4}{|c|}{ Ketuban pecah dini } & \multirow{3}{*}{ Total } & \multirow{3}{*}{ OR } & \multirow{3}{*}{ P-Value } \\
\hline & \multicolumn{2}{|c|}{$\mathbf{Y a}$} & \multicolumn{2}{|c|}{ Tidak } & & & \\
\hline & $\mathrm{N}$ & $\%$ & $\mathrm{~N}$ & $\%$ & & & \\
\hline Multipara & 14 & 8,9 & 45 & 28,7 & 59 & & \\
\hline Primipara & 18 & 11,5 & 80 & 52 & 98 & 0,41 & 1,38 \\
\hline Total & 32 & 20,4 & 125 & 79,6 & 157 & & \\
\hline
\end{tabular}

Berdasarkan tabel 6 terlihat bahwa responden yang mengalami Ketuban Pecah Dini ternyata lebih besar pada kelompok primipara sebanyak $18 \quad(11,5 \%)$ dibandingkan dengan kelompok multipara sebanyak 14 (8,9\%), Hasil uji statistic chisquare di peroleh nilai $\mathrm{p}$ value $0,41>0,05$ yang artinya tidak ada hubungan paritas dengan kejadian ketuban pecah dini. 
Tabel 7. Hubungan Jumlah Cairan ketuban Terhadap Kejadian Ketuban Pecah Dini pada Ibu Bersalin di BPM Sri Puspa Kencana, Amd.Keb Kabupaten Bogor Tahun 2020

\begin{tabular}{|c|c|c|c|c|c|c|c|}
\hline \multirow{3}{*}{ Jumlah cairan ketuban } & \multicolumn{4}{|c|}{ Ketuban pecah dini } & \multirow{3}{*}{ Total } & \multirow{3}{*}{ OR } & \multirow{3}{*}{ P-Value } \\
\hline & \multicolumn{2}{|c|}{$\mathbf{Y a}$} & \multicolumn{2}{|c|}{ Tidak } & & & \\
\hline & $\mathrm{N}$ & $\%$ & $\mathrm{~N}$ & $\%$ & & & \\
\hline Cukup & 31 & 19.7 & 119 & 75.8 & 59 & & \\
\hline Oligohidromion & 1 & 0,6 & 6 & 3,8 & 98 & 0,68 & 0,64 \\
\hline Total & 32 & 20,4 & 125 & 79,6 & 157 & & \\
\hline
\end{tabular}

Berdasarkan tabel 7 terlihat bahwa responden yang mengalami ketuban pecah dini ternyata lebih besar pada kelompok jumlah Ketuban Cukup sebanyak 31 $(19,7 \%)$ dibandingkan dengan kelompok Ogliohidromion sebanyak $1(0,6 \%)$. Hasil uji statistic chi-square di peroleh nilai $\mathrm{p}$ value $0,64>0,05$ yang artinya tidak ada hubungan jumlah cairan ketuban dengan kejadian ketuban pecah dini dari hasil analisis.

Tabel 8. Hubungan Kelainan Letak Janin Terhadap Kejadian Ketuban Pecah Dini Pada Ibu Bersalin di BPM Sri Puspa Kencana, Amd.Keb Kabupaten Bogor Tahun 2020

\begin{tabular}{|c|c|c|c|c|c|c|c|}
\hline \multirow{3}{*}{$\underset{\text { janin }}{\text { Kelainan letak }}$} & \multicolumn{4}{|c|}{ Ketuban pecah dini } & \multirow{3}{*}{ Total } & \multirow{3}{*}{ OR } & \multirow{3}{*}{ P-Value } \\
\hline & \multicolumn{2}{|c|}{ Ya } & \multicolumn{2}{|c|}{ Tidak } & & & \\
\hline & $\mathrm{N}$ & $\%$ & $\mathrm{~N}$ & $\%$ & & & \\
\hline Normal & 31 & 19.7 & 125 & 79,6 & 156 & & \\
\hline Sungsang & 1 & 0,6 & 0 & 0,0 & 1 & 0,04 & 0,19 \\
\hline Total & 32 & 20,4 & 125 & 79,6 & 157 & & \\
\hline
\end{tabular}

Berdasarkan tabel 8 terlihat bahwa responden yang mengalami ketuban pecah dini ternyata lebih besar pada kelompok letak normal sebanyak $31 \quad(19,7 \%)$ dibandingkan dengan kelompok letak sungsang sebanyak $1(0,6 \%)$. Hasil uji statistic chi-square di peroleh nilai p value $0,04>0,05$ yang artinya ada hubungan kelainan letak dengankejadianketuban pecah dini dengan hasil OR 0,19 artinya persalinan letak normal lebih beresiko 0,19 kali mengalami kejadian ketuban pecah 
JOURNAL OF MIDWIFERY CARE :

VOL. 02 No. 01, DESEMBER 2021

DOI : $10.34305 / J M C . V 2 I 01.364$
Ciptaan disebarluaskan di bawah

Lisensi Creative Commons Atribusi-

NonKomersial-BerbagiSerupa 4.0 Internasional

dini pada ibu bersalin dibandingkan bersalin.

dengan persalinan sungsang pada ibu

Tabel 9. Hubungan Usia terhadap Kejadian Ketuban Pecah Dini pada Ibu Bersalin di BPM Sri Puspa Kencana Kabupaten Bogor Tahun 2020

\begin{tabular}{|c|c|c|c|c|c|c|c|}
\hline \multirow{3}{*}{ Usia } & \multicolumn{4}{|c|}{ Ketuban pecah dini } & \multirow{3}{*}{ Total } & \multirow{3}{*}{ OR } & \multirow{3}{*}{ P-Value } \\
\hline & \multicolumn{2}{|c|}{ Ya } & \multicolumn{2}{|c|}{ Tidak } & & & \\
\hline & $\mathrm{N}$ & $\%$ & $\mathrm{~N}$ & $\%$ & & & \\
\hline Produktif & 14 & 43.8 & 74 & 59.2 & 59 & & \\
\hline Non produktif & 18 & 56.3 & 51 & 40.8 & 98 & 0,11 & 0,53 \\
\hline Total & 32 & 100. & 125 & 100 & 157 & & \\
\hline
\end{tabular}

Berdasarkan tabel 9 terlihat bahwa responden yang mengalami ketuban pecah dini ternyata lebih besar pada kelompok usia Non Produktif sebanyak 18 (56.3\%) dibandingkan dengan kelompok usia

\section{Pembahasan}

Analisis Univariat

Hasil uji statistic dengan menggunakan perhitungan chi square dengan SPSS menunjukan bahwa mayoritas ibu bersalin dengan Paritas di wilayah kerja BPM Sri Puspa Kencana, Amd.Keb dari 157 sampel menunjukan bahwa primipara sebanyak 98 (62.4\%). Penelitian ini juga sejalan dengan oleh Legawati pada tahun 2018 yang dilakukannya sebanyak 166 sample pada primipara 136 orang ( 81.9\%) lebih produktif sebanyak $14(43.8 \%)$, Hasil uji statistic chi-square di peroleh nilai $\mathrm{p}$ value $0,53>0,05$ yang artinya tidak ada hubungan paritas dengan kejadian ketuban pecah dini.

banyak di bandingkan dengan multipara 30 orang ( 18,8\%) (B. Rahayu \& Sari, 2017).

Hasil penelitian menunjukan bahwa ibu bersalin dengan Jumlah cairan ketuban di wilayah kerja BPM Sri Puspa Kencana, Amd.Keb dari 157 sample menunjukan bahwa ketuban yang cukup dengan cairan ketuban yang normal $150 \quad(95.5 \%)$. Penelitian ini juga sejalan dengan penelitian Dewi Yulia Sri pada tahun 2017 pada 85 sample dengan hasil jumlah variabel normal 56 responden $(65,9 \%)$ dan ogliohidromion 29 responden $(34,1 \%)$ (Rai et al., 2017). 
JOURNAL OF MIDWIFERY CARE :

VOL. 02 No. 01, DESEMBER 2021

DOI : $10.34305 / J M C . V 2 I 01.364$

Hasil penelitian menujukkan bahwa banyaknya ibu bersalin dengan Kelainan letak janin di wilayah kerja BPM Sri Puspa Kencana, Amd.Keb dari 157 sampel menunjukan bahwa kelainan letak janin normal sebanyak 156 (99,4\%). Penelitian ini juga sejalan dengan jurnal penelitian Lidia Widia sebanyak 203 (77,8\%) yang mengalami kejadian letak normal atau presentasi kepala dan sebanyak $7(22,2 \%)$ dengan letak sungsang yang mengalami ketuban pecah dini.

Hasil penelitian banyaknya ibu bersalin dengan Usia di wilayah kerja BPM Sri Puspa Kencana, Amd.Keb dari 157 sampel menunjukan bahwa usia produktif sebanyak 88 (56,1\%). Penelitian ini sejalan dengan jurnal Rahmawati tahun 2020 usia 35 tahun dan terdapat 27 (45\%) usia antara 20-35 tahun. pada 30 responden (Rahmawati, 2020).

Analisis Bivariat

Hasil uji statistic chi-square di peroleh nilai $\mathrm{p}$ value $0,41>0,05$ dengan hasil ini menunjukkan tidak terdapat hubungan antara kejadian ketuban pecah dini pada ibu bersalin dengan paritas. Penelitian ini sejalan dengan hasil penelitian jurnal budi rahayu tahun 2018 hubungan paritas dengan kejadian ketuban pecah dini
Ciptaan disebarluaskan di bawah

Lisensi Creative Commons Atribusi-

NonKomersial-BerbagiSerupa 4.0 Internasional

memiliki total sampling 247 kejadian KPD dengan hasil p-value 0,142 yang berarti tidak ada hubungan paritas dengan kejadian ketuban pecah dini pada ibu bersalin (A. Rahayu, 2018).

Hasil penelitian Hasil uji statistic chisquare pada SPSS di peroleh nilai $\mathrm{p}$ value $0,64>0,05$ hasil ini menunjukkan tidak terdapat hubungan antara kejadian ketuban pecah dini pada ibu bersalin dengan jumlah cairan ketuban (Kosim, 2016).. Penelitian ini tidak sejalan dengan uji penelitian Dewi Yulia Sri pada tahun 2017 yang di lakukan dengan total sampling 64 orang, p-value 0,000 artinya, adanya hubungan jumlah cairan ketuban dengan kejadian ketuban pecah dini pada ibu bersalin (Rai et al., 2017).

Hasil penelitian menunjukkan terdapat hubungan antara kejadian ketuban pecah dini pada ibu bersalin dengan kelainan letak janin Hasil uji statistic chi-square di peroleh nilai $\mathrm{p}$ value $0,04>0,05$ yang artinya ada hubungan kelainan letak dengan kejadian ketuban pecah dini dengan hasil OR 0,19 artinya persalinan letak normal lebih beresiko 0,19 kali mengalami kejadian ketuban pecah dini pada ibu bersalin dibandingkan dengan persalinan sungsang pada ibu bersalin. Penelitian ini sejalan dengan penelitian 
JOURNAL OF MIDWIFERY CARE :

VOL. 02 No. 01, DESEMBER 2021

DOI : $10.34305 / J M C . V 2 I 01.364$

jurnal penelitian Darul Azhar 2017 yang di lakukan dengan total sampling 210 , pvalue 0,03 menunjukan bahwa adanya hubungan kelainan letak dengan kejadian ketuban pecah dini. (Sakriawati \& Rahmawati, 2020).

Hasil penelitian dengan uji statistic chi-square di peroleh nilai $\mathrm{p}$ value $0,53>$ 0,05 menunjukkan tidak terdapat hubungan antara kejadian ketuban pecah dini pada ibu bersalin dengan usia. Penelitian ini sejalan dengan penelitian Sukriawati pada tahun 2020 bahwa faktor risiko Usia setelah dilakukan pengujian hipotesis menggunakan chi square tidak memiliki hubungan yang bermakna secara statistik dengan nilai $\mathrm{p}$ value $=0,299 \mathrm{OR}=0,365 \mathrm{Hal}$ ini berarti tidak ada hubungan faktor risiko usia dengan kejadian KPD (Sakriawati \& Rahmawati, 2020). Faktanya pada lapangan penelitian yang di lakukan banyaknya ibu bersalin dengan Usia Produktif dan Non Produktif tidak mempunyai faktor terjadinya KPD kejadian ini berbalik pola hidup sehat dan aktivitas ibu yang ibu jalani.

\section{Kesimpulan}

Diketahui kesimpulan pada penelitian yang menggunakan 157 sampel dan menggunakan pendekatan purposive
Ciptaan disebarluaskan di bawah

Lisensi Creative Commons Atribusi-

NonKomersial-BerbagiSerupa 4.0 Internasional

sampling dan rumus besar slovin dan menggunakan uji chi square pada SPSS dengan menggunakan teknik analisis data Univariat dan Bivariat adalah sebagai berikut ;

1. Paritas ibu bersalin menunjukan bahwa primipara yang mempunyai hasil presentase 98 (62.4\%), ketuban cukup yang mempunyai hasil presentase 31 (11,7\%), kelainan letak janin pada variable normal mempunyai hasil presentase 31 $(19,7 \%)$. usia pada variabel produktif mempunyai hasil presentase 14 $(8,9 \%)$,

2. Tidak terdapat hubungan antara paritas, jumlah cairan ketuban, juga usia dengan kejadian ketuban pecah dini dan terdapat hubungan antara kelainan letak dengan ketuban pecah dini.

\section{Saran}

Diharapkan dari hasil penelitian ini dapat meningkatkan ilmu pengetahuan pada ibu hamil khususnya tanda bahaya pada kehamilan menjelang persalinan untuk mendeteksi terjadinya Ketuban Pecah Dini. 


\section{Referensi}

Hartina, H. (2017). Manajemen Asuhan Kebidanan pada Bayi Ny " $M$ " dengan Kasus Caput Succedaneum di Rsud Syekh Yusuf Gowa Tahun 2017. Universitas Islam Negeri Alauddin Makassar.

Kementerian Kesehatan RI. (2017). Angka Kematian Ibu dan Bayi. http://jurnal.kemkes.angka-kematianibu-danbayi.ac.id/index.php/jkma/article/view /80/86

Kosim, M. S. (2016). Pemeriksaan Kekeruhan Air Ketuban. Sari Pediatri, 11(5), 379-384.

Manuaba, I. A. C. (2009). Buku Ajar Patologi Obstetri.

Profil Kesehatan Dinkes Kota Bogor. (2017). Data Kunjungan Pelayanan Kebidanan.

http://bppsdmk.dinkes.pelayanankebidanan-kotabogor.go.id/index.php/1665/30

Rahayu, A. (2018). Nutrition of the First Thousand Days of Life. CV Mine.

Rahayu, B., \& Sari, A. N. (2017). Studi deskriptif penyebab kejadian ketuban pecah dini (KPD) pada ibu bersalin. Jurnal Ners Dan Kebidanan Indonesia, 5(2), 134-138.

Rai, N., Kumar, R., Haque, A., Hassan, I., \& Dey, S. (2017). Изучение рекомбинантных сестринов 1 и 2 человека, продуцируемых в прокариотической системе. Молекулярная Биология, 51(3), 473482.
Ciptaan disebarluaskan di bawah

Lisensi Creative Commons Atribusi-

NonKomersial-BerbagiSerupa 4.0 Internasional

Sagita, Y. D. (2016). Hubungan Antara Ketuban Pecah Dini dan Persalinan Sectio Caesarea dengan Kejadian Asfiksia pada Bayi Baru Lahir. Aisyah: Jurnal Ilmu Kesehatan, 1(1), 195284.

Sakriawati, M., \& Rahmawati, R. (2020). Faktor Risiko Usia Dan Paritas Ibu Hamil Terhadap Kejadian Ketuban Pecah Dini. Nursing Arts, 14(2), 9097.

Sunarti, S. (2017). Manajemen Asuhan Kebidanan Intranatal pada Ny " $R$ " Gestasi 37-38 Minggu dengan Ketuban Pecah Dini (KPD) di RSUD Syekh Yusuf Kabupaten Gowa Tahun 2017. Universitas Islam Negeri Alauddin Makassar.

Wulandari, I. A., Febrianti, M., \& Octaviani, A. (2019). Faktor-Faktor yang Berhubungan Terhadap Kejadian Ketuban Pecah Dini (KPD) di RSIA Sitti Khadijah I Makassar Tahun 2019. Jurnal Kesehatan Delima Pelamonia, 3(1), 52-61. 